\title{
Omskjæring kun på medisinsk indikasjon
}

\author{
Omskjæring av gutter skjer overalt i verden. Mange krever nå forbud mot denne egentlig unødvendige \\ operasjonen, blant andre det nye barneombudet. Et slikt krav viser manglende sensitivitet overfor hva \\ et forbud vil bety.
}

I jødedommen er omskjæring et religiøst påbud. Også muslimer praktiserer omskjæring, men så vidt jeg vet er det ikke noe religiøst påbud, det må regnes som et tradisjonelt ritual. Ifølge historiske kilder skal andre semittiske folk ha praktisert omskjæring på gutter i flere tusen år - like lenge som jødene. Jeg har selv i noen måneder arbeidet i ørkenstrøk med daglige virvelvinder og har måttet grave ut sand fra barns nese, ører og munn. Noen mener at kanskje sand under preputiet var årsak til at skikken med omskjæring oppsto nettopp i disse strøk.

I USA blir de fleste gutter omskåret. Når og hvorfor oppsto denne praksisen? Omkring 1860 ble praktisk talt ingen menn i USA omskåret (1). Det året sto det en artikkel i The Lancet der omskjæring ble

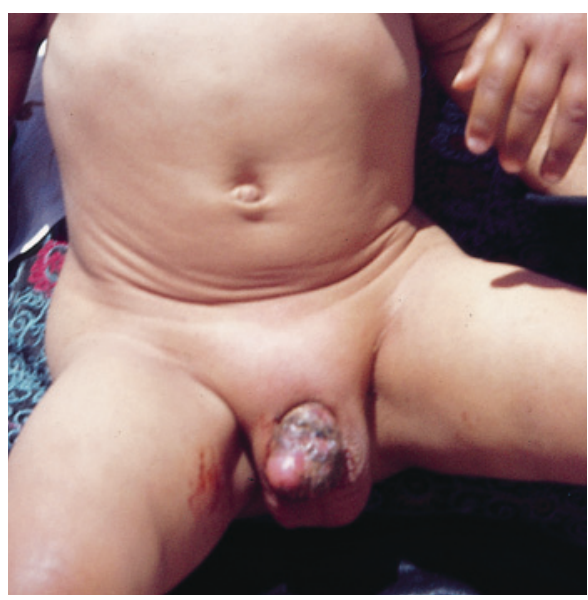

Omskåret av lokal «lege». Foto Helene Pande anbefalt som et effektivt middel mot onani (2). Inngrepet skulle gjøres uten kloroform, slik at smerte ville bli assosiert med den vanen man ønsket å utrydde (eradicate). De neste årene kom det en rekke artikler der man argumenterte for omskjæring som et effektivt middel først og fremst mot onani, men også mot alvorlige nevrologiske lidelser.

Inngrepet økte raskt i omfang, og i 1900 ble det oppgitt at $25 \%$ av amerikanske menn var omskåret. Etter hvert kom det innvendinger, og i 1971 skrev American Academy of Pediatrics: «There are no valid indications for circumcision in the neonatal period» (3). Senere har organisasjonen vinglet litt frem og tilbake. I siste uttalelse, fra september 2012, mente den at fordelene i form av færre urinveisinfeksjoner i første leveår, færre infeksjoner og mindre penil cancer senere teller mer enn ulempene (4). Denne uttalelsen har møtt motbør.

Hva med forbud mot omskjæring av gutter i Norge? For noen av oss som forsøker å forsvare andre gruppers tradisjoner og ritualer er forbud en uting som fort kan smitte over til mangel på respekt og anerkjennelse av andre vaner og skikker. Men det finnes også andre veier. $\mathrm{Og}$, som så ofte før, finner jeg at man i Storbritannia har gode løsninger. Allerede i 1948 hadde National Health Service en bestemmelse om at de bare dekker omskjæring gjort på medisinsk indikasjon. Antallet omskjæringer er gått ned etter at denne bestemmelse er blitt blir mer og mer brukt.

Kan ikke vi gjøre det samme? Kan ikke den nye helseministeren gripe inn - uten å nedsette komiteer og be om årelange utredninger? Det blir innvendt at ved å ta tradisjonell omskjæring ut av refusjonssystemet, vil antallet komplikasjoner øke. Legevaktene har visstnok allerede en del vonde eksempler å vise til. Men så får vi bruke de forbud, lover og regler vi allerede har. Med eller uten lisens bør man holdes ansvarlig og eventuelt straffes for å utføre dårlig kirurgisk håndverk.

\section{Helene Pande}

helene.pande@getmail.no

Helene Pande (f. 1928) er pensjonert barnelege. Forfatter har fylt ut ICMJE-skjemaet og oppgir ingen interessekonflikter

\section{Litteratur}

1. A short history of circumcision in the US. www.whale.to/a/circumcision 1.html (14.10.2012).

2. Johnson AAW. On an injurious habit occasionally met with in infancy and early childhood. Lancet 1860; 75: 344-5.

3. American academy of pediatrics circumcision statements. www.cirp.org/library/statements/aap/ (13.10.2012).

4. Circumcision policy statement. Task force on circumcision. Pediatrics 2012; 130: 585-6. http://pediatrics.aappublications.org/content/130/ 3/585 (13.10.2012).

Mottatt 28.9. 2012, første revisjon innsendt 15.10. 2012, godkjent 18.10. 2012. Medisinsk redaktør Erlend Hem.

Publisert først på nett 2.11. 2012 